Editorial

\title{
Housing and Socio-Spatial Inclusion
}

\author{
Dallas Rogers ${ }^{1, *}$, Rae Dufty-Jones ${ }^{1}$ and Wendy Steele ${ }^{2}$ \\ ${ }^{1}$ School of Social Science and Psychology, University of Western Sydney, Parramatta, NSW 2150, Australia; \\ E-Mails: d.rogers@uws.edu.au (D.R.),r.dufty-jones@uws.edu.au (R.D.-J.) \\ ${ }^{2}$ Global, Urban and Social Studies, RMIT University, Melbourne, Victoria 3000, Australia; \\ E-Mail: wendysteele@rmit.edu.au \\ * Corresponding author
}

Submitted: 9 March 2015 | Published: 9 April 2015

\begin{abstract}
This special issue on housing and socio-spatial inclusion had its genesis in the $5^{\text {th }}$ Housing Theory Symposium (HTS) on the theme of housing and space, held in Brisbane, Australia in 2013. In late 2013 we put out a call for papers in an attempt to collect an initial suite of theoretical and empirical scholarship on this theme. This collection of articles progresses our initial discussions about the theoretical implications of adding the "social" to the conceptual project of thinking through housing and space. We hope that this special issue will act as a springboard for a critical review of housing theory, which could locate housing at the centre of a much broader network of social and cultural practices across different temporal trajectories and spatial scales. This editorial presents an overview of the theoretical discussions at the HTS and summarises the six articles in this themed issue, which are: (1) The meaning of home in home birth experiences; (2) Reconceptualizing the "publicness" of public housing; (3) The provision of visitable housing in Australia; (4) The self-production of dwellings made by the Brazilian new middle class; (5) Innovative housing models and the struggle against social exclusion in cities; and (6) A theoretical and an empirical analysis of "poverty suburbanization".
\end{abstract}

\section{Keywords}

housing; inclusion; interstitial; place defending; poverty; public; private; social; space; suburbanization; verticality

Issue

This editorial is part of the special issue "Housing and Space: Toward Socio-Spatial Inclusion”, edited by Dr. Dallas Rogers (University of Western Sydney, Australia), Dr. Rae Dufty-Jones (University of Western Sydney, Australia) and Dr. Wendy Steele (RMIT University, Australia).

(C) 2015 by the authors; licensee Cogitatio (Lisbon, Portugal). This article is licensed under a Creative Commons Attribution 4.0 International License (CC BY).

\section{Housing and Space: Reflections from the 5th Housing Theory Symposium}

This special issue on housing and socio-spatial inclusion had its genesis in the $5^{\text {th }}$ Housing Theory Symposium (HTS) on the theme of housing and space, held in Brisbane, Australia in 2013. Some of the highlights of the $5^{\text {th }}$ HTS include Stephen Graham's keynote address on the verticality of cities and urban space. Graham's (2014) provocative inclusion of a vertical politics of space, as both a compliment to and challenge against a horizontal socio-spatial-centrism in studies of urbanity, provides a fitting contextual frame for this special issue. Graham's contribution forces us to rethink horizontal theories of urban space by shifting the conceptual axis of the Cartesian coordinate system from the $x$ to the $y$-from a flat urban ontology of city landscapes towards a three dimensional politics of high-rise urban space and the "aerial view". His critique of horizontal mapping and planning was both timely and significant (Graham, 2014). The increasing verticality of cities requires us to reconceptualise urban space as a dialectical vertical-horizontal spatial practice. To question where the new class lines might be drawn within vertical cities at the level of the individual, or to inquire about the structural implications of the three dimensional city, are but only two of a 
whole set of emergent research questions and theoretical tasks. How should we theorise the stairs leading down into underground basement housing in Beijing (Schindler, 2014), or the lifts up into gated penthouse apartments in Latin American cities (Borsdorf \& Hidalgo, 2008) within the vertical politics of urban space? These are questions still to be explored, but we know that these vertical spatial practices will increasingly demarcate and locate people and places in new ways.

Following from Graham's city-level contextual reframing of urban space, the second keynote address by Robyn Dowling turned to the scale of the home. Drawing on international collaborative work with Harriet Bulkeley (Durham University) and Pauline McGuirk (Newcastle University) the focus was on housing and home interventions in Carbon Reduction Projects. Their emphasis is on the need to reconceptualise houses and households as central to critical interrogations of, and responses to, climate change. Collectively their work develops deeper understandings of housing, domestic spaces and governance through: i) an investigation of how house and home are becoming governmental sites in the project of carbon reduction; and ii) how related governance interventions are reshaping notions of home and homemaking identities. With an emphasis on two Sydney-based interventions-the City of Sydney's Smart Green Apartments and the Smart Grid Smart City retail trial-Dowling et al. seek to contribute to a better understanding of the home-making subject as a key site in/though which the "conduct of carbon conduct" is governed (Dowling, McGuirk, \& Bulkeley, 2014; McGuirk, Bulkeley, \& Dowling, 2014).

Building on the spatial focus of housing and home, Wendy Steele and Cathy Keys explored the interstitial spaces between spaces and focused their analysis on the liminal spaces within the home. Steele and Keys explored the use of the interstitial spaces within the build form of the home as an important place to store familial objects. They used the iconic Australian "Queenslander" housing type as a case study. The Queenslander typically consists of a low-set timber house with wrap-around verandas and an elevated underfloor supported by long supporting timbers beams stretching down to the ground. Steele and Keys used the interstitial spaces underneath the Queenslander to theorise these inbetween spaces as an important part of the Australian psyche. They contrast the placement of important family objects into the interstitial spaces of the Queenslander with the older practice of Indigenous Australians, where the small space between the bed and the wall of a temporary natural shelter is used to store personal belongings in an otherwise collectivist culture of shared belongings. The spaces between spaces within the home represent an important site for investigating the intersection and perhaps clash of individual and collective identities (Steele and Keys 2015).

Lucy Groenhart conducted-what we would call-a genealogy of housing theory. Groenhart provided a history of housing theory from 1945 through to the early $21^{\text {st }}$ century. The implication of Groenhart's work (although this might not have been Groenhart's aim) is that a genealogy of housing theory can demonstrate the very limits of our historical knowledge about housing practices and systems. That is, we build housing histories by drawing on, and through, the theories, analyses and reporting that is popular or available at particular points in time. But how do we account for the housing theories that are not popular or available? We think this type of questioning disrupts the idea that we can create a reliable history of housing theory and practice in the present and is worthy of further exploration. Keeping with this structural and historical focus, Ilan Wiesel tracked the politics of deinstitutionalisation and housing to showcase how the shifting policy frameworks in Australia were underwritten by discourses of "normalisation" to "choice" (Wiesel \& Bigby, 2015).

Dallas Rogers (2013), Jacqueline Nelson (2013) and Rae Dufty-Jones (2012) brought their housing and racism scholarship into conversation to examine the desire to protect a social, cultural or geographical space from the other as a process of place-defending (Nelson, 2014). They showed that place defending includes, but is certainly not limited to: physical and emotional violence against minority groups that are constructed as invading a majority group's space (Nelson, 2013; Poynting, 2006); local political and discursive resistance toward providing (Davison et al., 2013) or removing (Rogers \& Darcy, 2014) affordable housing projects; national political and discursive resistance to acknowledging the claims of asylum seekers (Magner, 2004); monitoring and policing gendered or radicalized spatial practice (Amin, 2012); sensory conflicts, such as cooking smells or cultural music performances, within urban spaces (Wise, 2010); and housing morphologies within urban areas whereby an imagined other threatens to invade a space through their occupation of newly constructed housing projects (Rogers, 2014).

The $5^{\text {th }}$ HTS concluded with six PhD papers and a PhD panel discussion. Ying-ying Li deployed Heidegger (1927) to theorise place attachment and earthquake reconstruction in China. Marta Botta used futurology theories and the work of Sohail Inayatullah (1998) to present a revolutionary and somewhat utopian call for a structural overhaul of the capitalist housing system. Along with Gordon Bijen (Bijen \& Piracha, 2012), Anne-Sophie Lotti followed her French compatriot Henri Lefebvre (1968) to deploy the Right to the City as a tool for a radical rethinking of housing politics and space. Finally, Angela Ballard tapped into the work of Paulo Freire (1970) to pitch the neologism "autoethnica".

\section{Contributions to This Special Issue: Housing and Socio-Spatial Inclusion}

At the conclusion of the 2013 HTS one key theme clear- 
ly emerged in the concluding summation - the question of the relationships between housing, social and spatial theory and practice. This special issue on housing and socio-spatial inclusion developed from our initial discussions about the implication of adding the "social" to the conceptual project of thinking through housing and space. In late 2013 we put out a call for papers in an attempt to collect an initial suite of theoretical and empirical scholarship on this theme. We hope that this special issue will act as a springboard for a critical review of housing theory, which could locate housing at the centre of a much broader network of social and cultural practices across different temporal trajectories and spatial scales. This special issue presents six articles on related themes: (1) The meaning of home in home birth experiences; (2) Reconceptualizing the "publicness" of public housing; (3) The provision of visitable housing in Australia; (4) The self-production of dwellings made by the Brazilian new middle class; (5) Innovative housing models and the struggle against social exclusion in cities; and (6) A theoretical and an empirical analysis of "poverty suburbanization".

Emily Burns' article, entitled More than four walls: The meaning of home in home birth experience, is an ambitious contribution covering the disciplines of medicine, health, sociology and midwifery. It outlines a fascinating case study of home birthing to showcase the tensions between home and hospital birth. It recasts the often-discussed "hospital versus home" birthing debate by locating the subjective and embodied home at the centre of women's childbirth experience and decision-making process. The qualitative study draws on 58 interviews with home birthing women in Australia. Burns argues that "Home, for the participants in this study, is a dynamic, changing, and even spiritual element in the childbirth experience, and not simply the building in which [child birthing] occurs" $(2015$, p. 6). In Burns' discussion the home is drawn into theoretical debates about safety, risk, agency and the medicalization of birthing. The home, for many of the women in this study, is a place to contest the actors that seek to control women's maternal and neonatal health.

Nele Aernouts and Michael Ryckewaert's article, entitled Reconceptualizing the "publicness" of public housing: The case of Brussels, is a theoretical examination of the way in which conceptual linkages between housing and notions of the "public" are made and unmade. They deploy a complex suite of housing, spatial and political theory, covering Habermans, Arendt, Marcuse, Arnstein, Kemeny and Forrest to name a few. They locate their analysis in various notions of "the commons" and focus in particular on what is "public" about public housing in Brussels. The historical analysis covers a set of different public housing models. The comparative analysis is based on a set of criteria that the authors extract from commons theory. They conclude their article by positing four core dimensions that underwrite their model: ownership, co-production, community activity and physical configuration.

Margaret Ward and Jill Franz's article, entitled The provision of visitable housing in Australia: Down to the detail, takes the discussion about socio-spatial inclusion into the regulatory spaces of the Australian government. They draw on the United Nations Convention of the Rights of People with Disabilities (CRPD) and explore the challenges of a voluntary (versus a regulated) adaptable housing design framework in Australia. Using the Livable Housing Design agreement and a case study of eleven newly-constructed dwellings in three housing contexts in Brisbane, Australia, they argue that a system whereby the various housing industries voluntarily adopt a set of national guidelines "is unrealistic and that mandatory regulation will be necessary for any lasting transformation to occur" (2015, p. 31).

Priscilla Nogueira's article, entitled Battlers and their homes: About self-production of dwellings made by the Brazilian new middle class, takes the discussion about socio-spatial inclusion to Brazil. It covers the emergence of the new middle class and the resultant socio-spatial reorganisation of neighbourhoods by various actors. Nogueira interrogates questions relating to the different knowledges that underwrite urban planning, the various building and construction techniques used by different actors and the socio-economic disparities relating to government policy and housing provision. At the centre of this critique is a question that is common to nation-states with rapid economic grown and large numbers of people still living in poverty; and that is, will the socio-economic benefits of urban and economic growth flow down to the poorest citizens?

Picking up on a common theme running through all the articles in this special issue, Naomi Hay and Petra Simona Perolini approach the question of socio-spatial inclusion and housing from the opposite direction. Their article, entitled The role innovative housing models play in the struggle against social exclusion in cities: The Brisbane common ground model, presents a case of (in their words) socio-spatial exclusion. Drawing on the scholarship of Mumford to Lefebvre, they start with a critique of Australia's private property driven home ownership market and link this analysis to Australia's "housing affordability crisis". Using Henri Lefebvre's notion of A Right to the City, they argue that housing discrimination is a structural rather than an individual problem. They set out their claims with an empirical case study of the Common Ground approach in Brisbane, Australia.

The final article continues with the socio-spatial exclusion theme by expanding the analysis to the level of "the urban". Entitled Poverty suburbanization: Theoretical insights and empirical analyses, Kenya L. Covington presents an all too common picture of increasing urban poverty in the US. Covington (2015) identifies a set of structural factors that could be associated with the 
suburbanization of the poor and argues that poverty suburbanization has accelerated over the last decade. Covington concludes by highlighting a common barrier to urban change, that "there are powerful forces including political, economic and social that aid particular individuals, and organizations in shaping the urban landscape in ways that continue to work in their favour" (p. 87).

\section{Acknowledgements}

Dallas Rogers, Rae Dufty-Jones and Wendy Steele would like to thank the University of Western Sydney and Griffith University for providing funding for the 2013 Housing Theory Symposium, and Griffith University for hosting the event. We would also like to thanks all the presenters at the event and the authors of the articles in this special issue.

\section{Conflict of Interests}

The authors declare no conflict of interests.

\section{References}

Aernouts, N., \& Ryckewaert, M. (2015). Reconceptualizing the "publicness" of public housing: The case of Brussels. Social Inclusion, 3(2), 17-30.

Amin, A. (2012). Land of strangers. Cambridge: Polity.

Bijen, G., \& Piracha, A. (2012). Evaluating the urban design and community life in public housing in Australia. Australian Planner, 49(4), 349-360. doi:10.1080/07293682.2012.678872

Borsdorf, A., \& Hidalgo, R. (2008). New dimensions of social exclusion in Latin America: From gated communities to gated cities, the case of Santiago de Chile. Land Use Policy, 25(2), 153-160. doi:http: //dx.doi.org/10.1016/j.landusepol.2007.04.001

Burns, E. (2015). More than four walls: The meaning of home in home birth experience. Social Inclusion, $3(2), 6-16$.

Covington, K. L. (2015). Poverty suburbanization: Theoretical insights and empirical analyses. Social Inclusion, 3(2), 71-90.

Davison, G., Legacy, C., Lui, E., Han, H., Phibbs, P., van de Nouwelant, R., Darcy M., \& Piracha, A., (2013). Understanding and addressing community opposition to affordable housing development (Research Report). Melbourne: Australian Housing and Urban Research Institute. Retrieved from http://www. ahuri.edu.au/publications/projects/p71007

Dowling, R., McGuirk, P. M., \& Bulkeley, H. (2014). Retrofitting cities: Local governance in Sydney, Australia. Cities, 38, 18-24.

Dufty-Jones, R. (2012). Moving home: Theorizing housing within a politics of mobility. Housing, Theory and Society, 29(2), 207-222. doi:10.1080/
14036096.2011.641262

Freire, P. (1970). Pedagogy of the Oppressed. New York: Herder and Herder

Graham, S. (2014). Super-tall and Ultra-deep: The cultural politics of the elevator. Theory, Culture \& Society, 31(7-8), 239-265. doi:10.1177/026327641 4554044

Hay, N., \& Simona, P. (2015). The role innovative housing models play in the struggle against social exclusion in cities: The Brisbane common ground model. Social Inclusion, 3(2), 62-70.

Heidegger, M. (1927). Being and time (1 ed.). Oxford: Blackwell Publishing.

Inayatullah, S. (1998). Causal layered analysis: Poststructuralism as method. Futures, 30(8), 815829. doi:http://dx.doi.org/10.1016/S0016-3287(98) 00086-X

Lefebvre, H. (1968). The right to the city. Paris: Anthropos. Magner, T. (2004). A Less than "pacific" solution for asylum seekers in Australia. International Journal of Refugee Law, 16(1), 53-90. doi:10.1093/ijrl/16.1.53

McGuirk, P., Bulkeley, H., \& Dowling, R. (2014). Practices, programs and projects of urban carbon governance: Perspectives from the Australian city, Geoforum, 52, 137-147.

Nelson, J. K. (2013). Denial of racism and its implications for local action. Discourse \& Society, 24(1), 89-109. doi:10.1177/0957926512463635

Nelson, J. K. (2014). Place defending and local antiracism. Australia Journal of Social Issues, 49(1), 6785.

Nogueira, P. (2015). Battlers and their homes: About self-production of dwellings made by the Brazilian new middle class. Social Inclusion, 3(2), 44-61.

Poynting, S. (2006). What caused the Cronulla riot? Race and Class, 48(85), 85-92.

Rogers, D. (2013). The Poetics of cartography and habitation: Home as a repository of memories. Housing, Theory and Society, 30(3),1-19. doi:10. 1080/14036096.2013.797019

Rogers, D. (2014). The Sydney Metropolitan Strategy as a zoning technology: Analyzing the spatial and temporal dimensions of obsolescence. Environment and Planning D: Society and Space. 32(1), 108-127.

Rogers, D., \& Darcy, M. (2014). Global city aspirations, graduated citizenship and public housing: Analysing the consumer citizenships of neoliberalism. Urban, Planning and Transport Research, 2(1), 1-17. doi: 10.1080/21650020.2014.906906

Schindler, S. (2014). Understanding urban processes in flint, michigan: Approaching "subaltern urbanism" inductively. International Journal of Urban and Regional Research, 38(3), 791-804. doi:10.1111/ 1468-2427.12082

Steele, W., \& Keys, C. (2015). Interstitial space and everyday housing practices. Housing, Theory and Society, 32(1), 112-125. 
Ward, M., \& Franz, J. (2015). The provision of visitable housing in Australia: Down to the detail. Social Inclusion, 3(2), 31-43.

Wiesel, I., \& Bigby, C. (2015). Movement on shifting sands: Deinstitutionalisation and people with intellectual disability in Australia, 1974-2014.
Urban Policy and Research, (ifirst), 1-17. doi:10. 1080/08111146.2014.980902

Wise, A. (2010). Sensuous multiculturalism: Emotional landscapes of inter-ethnic living in Australian suburbia. Journal of Ethnic and Migration Studies, 36(6), 917-937.

\section{About the Authors}

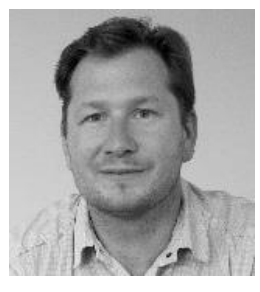

\section{Dr. Dallas Rogers}

Dallas Rogers is a Lecturer in Urban Studies at the University of Western Sydney. Dallas is an urban geographer investigating the relationships between urban space, discourse networks, housing actors, poverty and wealth. He has undertaken a critical analysis of Australian urbanism through fine-grained empirical research with low-income public housing tenants as well as super-rich transnational property investors and their agents. His current research focus is on a relational examination of housing poverty and wealth in globalising cities.

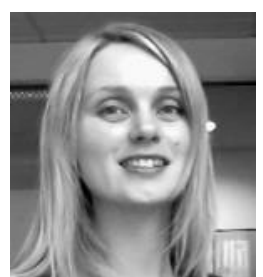

\section{Dr. Rae Dufty-Jones}

Rae Dufty-Jones is a Senior Lecturer in Geography and Urban Studies at the University of Western Sydney. Rae is an economic and social geographer who researches mobility, housing, neoliberal governance and urban and regional development. Her current research projects include: "Mobility aspirations of tenants listing on the 'Our House Swap' website" and the "Werrington Park Corporate Centre Monitoring and Evaluation”.

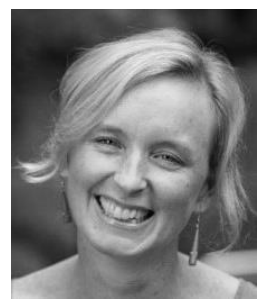

\section{Dr. Wendy Steele}

Wendy Steele is an Associate Professor and Australian Research Council (DECRA) Fellow in the Centre for Urban Research at RMIT University, Melbourne. Her research focuses on urban climate justice and rethinking critical urban infrastructure (including housing) in a climate of change. 